\title{
NF1 wt Allele
}

National Cancer Institute

\section{Source}

National Cancer Institute. NF1 wt Allele. NCI Thesaurus. Code C52882.

Human NF1 wild type allele is located in the vicinity of $17 \mathrm{p} 11.2$ and is approximately 279 $\mathrm{kb}$ in length. This allele, which encodes neurofibromin protein, may be involved in the attenuation of Ras signal pathway. Mutations in this allele are associated with type I neurofibromatosis, juvenile myelomonocytic leukemia and Watson syndrome. 